\title{
Silicon-enhanced Resistance of Plants to Biotic Stresses Review article
}

\author{
N. SAKR \\ Department of Agriculture, Atomic Energy Commission of Syria, Damascus, P.O. Box 6091, Syria
}

(Received: 13 April 2017; accepted: 24 January 2018)

\begin{abstract}
The emerging role of silicon ( $\mathrm{Si}$ ) has attracted a great deal of interest from researchers because of the numerous agronomic benefits of this element to plants. Indeed, silicon improves plant resistance to a range of biotic and abiotic stresses, with consequent yield increases. Furthermore, it enhances resistance in several crops of great economic importance to diseases and insect pests. Until recently, the exact nature of protective effects of silicon in plants is uncertain. To date, two major defense mechanisms due to silicon application have been documented: physical defense and biochemical defense. In this review, the interaction between silicon-treated-plants and reduced biotic stresses (disease and insect pests) incidence was explored. The current research presents the agronomic importance of silicon in plants, the control of fungal and bacterial pathogens and insect pests according to their lifestyle, and viral agents, and different mechanisms of silicon-enhanced resistance. By regrouping the data presented in this paper, a good knowledge of the association between silicon treatment, increasing plant resistance, and decreasing biotic stresses occurrence could be achieved.
\end{abstract}

Keywords: Diseases, insect pests, silicon application.

One of the major constraints of plant crop production is protecting the foliage from diseases and insect pests (Semal, 1989; Ukwungwu, 1990). Chemicals and resistant rootstocks are wildly used as traditional protecting methods to decrease the intensity of diseases and insect pest infestation (Denholm and Rowland, 1992; Dubin and Rajaram, 1996; Shephard, 1997). However, chemical control limitations, high costs, equipment needed and labor greatly contribute to the cost of production. Furthermore, toxicological problems as persistence in food and/or environment and possibility of developing resistant populations due to frequent use and/or overuse of the same conventional chemicals reduce their effectiveness (Cooksey, 1990; Denholm and Rowland, 1992; Ma and Michailides, 2005). Also, intensive resistance selection pressure, if such resistant cultivars is available, emerged new pathogenic strains, and hence resistance breakdown (Lindgren, 1997; Bayles et al., 2000). Other disease and insect pest control methods remain to be urgently sought and investigated. Enhanced plant silicon nutrition can be a potential strategy and an alternative environment-friendly approach to prevent or at least suppresses biotic and abiotic stresses, with a consequent increase in yield (Datnoff et al., 2007). Silicon- 
improved plant resistance has been reported to a wide range of fungal, bacterial and viral pathogens, and insect pests including borers and sap-feeding insects (Ma, 2004; Ma and Yamaji, 2006; Datnoff et al., 2007; Liang et al., 2007, 2015a,b,c; Van Bockhaven et al., 2013; Sakr 2016a,b, 2017; Reynolds et al., 2016).

In general, two mechanisms in which silicon can reduce the severity of diseases and insect pests have been reviewed: physical defense and induced biochemical defense (Fig. 1) (Ma, 2004; Liang et al., 2007, 2015a,b,c; Van Bockhaven et al., 2013; Reynolds et al., 2016; Sakr, 2016a,b, 2017). The first one is associated with an accumulation of absorbed silicon in the epidermal tissue, and the second one is related to an expression of metabolic or pathogenesis-mediated host defense responses. Other silicon-enhanced resistance mechanisms could be specific as described to some bacterium and viral pathogens (Sakr, 2016a).

To date, silicon application has been documented in controlling and reducing the incidence and severity of fungal, bacterial and viral diseases, and insect growth and reproduction in both monocotyledons and dicotyledons (Table 1). Under a range of abiotic and biotic stresses, the effect of silicon, its mode of action and its function are uncertain and presently a subject of debate (Ma, 2004; Liang et al., 2007, 2015a,b,c). However, silicon treatments induced physical and/or biochemical protection systems against all fungal, bacterial and insect feeding guilds: necrotrophic, hemibiotrophic and biotrophic fungal pathogens, epiphytic and endophytic bacterial pathogens, and lepidopteran borer and sap-feeding pest insects (Van Bockhaven et al., 2013; Liang et al., 2015a,b; Reynolds et al., 2016; Sakr, 2016a,b, 2017). Also, economically important viral diseases in crop plants are efficiently controlled by silicon treatments. In order to understand the complex interaction between silicon applications and disease and insect pest resistance in plants, this review aims to (1) underline the agricultural importance of silicon in plants, (2) refer to the control of fungal and bacterial pathogens and insect pests according to their lifestyles, and viral agents, and (3) explain several mechanisms of silicon-augmented resistance.

\section{Silicon in plants}

According to the classical definition of essentiality, Arnon and Stout (1939) defined three universally criteria required for plant nutrition, and they recognized that silicon is not essential for plants because it is not involved in the structure or metabolism of the plants. However, silicon is considered as essential due to abnormalities in growth, development and reproduction in silicon-deficient plants (Epstein and Bloom, 2005). In many plant species, it enhances plant resistance against abiotic and biotic stresses, and the resistance mechanisms are now beyond doubt because they may act in the soils, at the root surface and in planta (roots and shoots) (Ma, 2004; Liang et al., 2007, 2015a,b,c).

Silicon is the second most abundant element in the earth's crust mass $(27.70 \%)$ and in the soil (50 to $400 \mathrm{~g} \mathrm{Si} \mathrm{kg}^{-1}$ ) (Kovda, 1973). In the soil, low solubility of silicon compounds (present mainly as $\mathrm{SiO}_{2}$, up to $70 \%$ of the soil mass) is the main reason that silicon is not available for plant uptake (Rizwan et al., 2012). In soil solution, silicon occurs primarily as water-soluble monosilicic acid $\left(\mathrm{H}_{4} \mathrm{SiO}_{4}\right)$ at concentrations ranging from 0.1 to $0.6 \mathrm{mM}$ influenced by its solvation from inorganic substances and its adhesion or absorption by the soil (Epstein, 1994; Savant et al., 1997). Plant roots easily take up silicon in the 


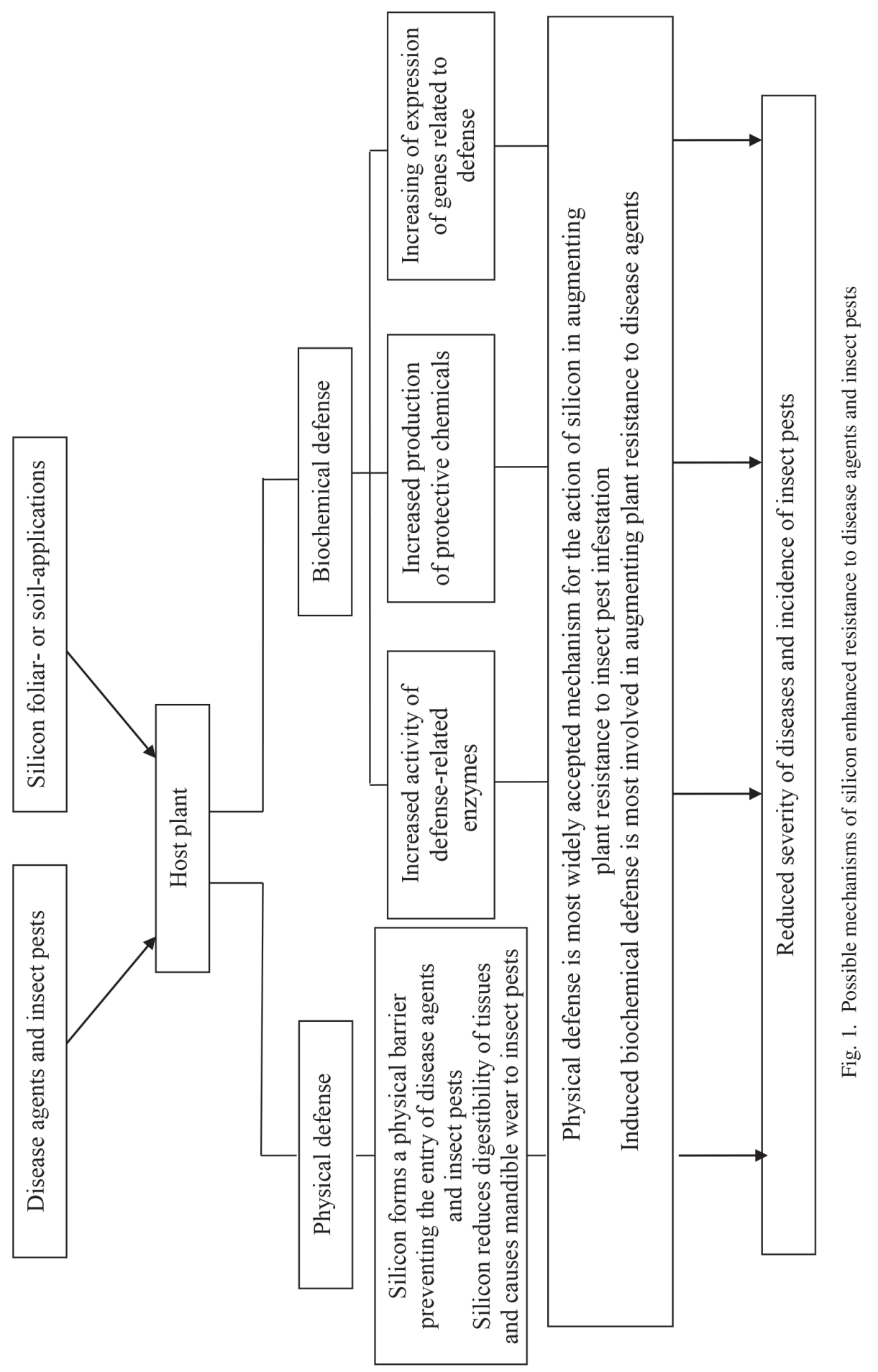


form of uncharged monosilicic acid at $\mathrm{pH}$ below 9 through a passive process regulated by transpiration stream (Epstein, 1994). Once absorbed, it is transported via xylem to all parts of the plant and polymerized into insoluble silica $\left(\mathrm{SiO}_{2} \cdot \mathrm{nH}_{2} \mathrm{O}\right)$ immediately below the cuticle, and it forms a physical barrier called double layer silicon-cuticle (Ma et al., 2011).

Applications of silicon treatments have many agricultural benefits including improved plant architecture, growth, yield and productivity, photosynthetic capacity, tolerance to frost and drought, enzyme activity, positive interactions with applied $\mathrm{N}, \mathrm{P}$ and $\mathrm{K}$ fertilizers (Savant et al., 1997). Silicon nutrition decreases the incidence and severity of fungal, bacterial and viral diseases, and insect pest infestation in several crop plant species (Ma, 2004; Silva et al., 2010; Zellner et al., 2011; Van Bockhaven et al., 2013; Liang et al., 2015a,b; Reynolds et al., 2016; Sakr, 2016a,b, 2017). Most importantly, silicon improved plant resistance against a multitude of stresses without the occurrence of resistance tradeoffs and/or growth and yield penalties (Ma, 2004; Ma and Yamaji, 2006; Epstein, 2009; Van Bockhaven et al., 2013; Liang et al., 2015b).

Epstein $(1994,1999,2009)$ reported that the absorption of silicon by plants from the soil at differing rates depend on genotype, its concentration in the soil and environmental conditions. Silicon absorption capacity from the soil recorded 300-700 kg Si ha ${ }^{-1}$ in sugarcane, $150-300 \mathrm{~kg} \mathrm{Si} \mathrm{ha}^{-1}$ in rice, and 50-150 kg Si ha ${ }^{-1}$ in wheat (Bazilevich, 1993). According to Ma and Yamaji's (2006) agricultural point of view, plants can be divided as silicon accumulators (silicon concentrations greater than $1 \%$ ), silicon intermediate and low accumulator (silicon concentrations less than $0.1 \%$ ) or silicon-rejecters. Silicon accumulation capacity among species is due to differences in silicon transporters and distinct mechanisms of silicon transported via xylem (Ma and Yamaji, 2008). In general, graminaceous plants, such as wheat, oat, rye, barley, sorghum, maize, and sugarcane, absorb and accumulate much higher silicon than dicotyledon plants, such as soybeans and cucumber and other crops (Epstein, 1999; Ma and Yamaji, 2006).

\section{Silicon in controlling diseases and insect pests}

It is well established that silicon controls diseases and insect pests of economically important crops. A positive relationship between silicon and reduced disease intensity of fungal, bacterial and viral pathogens, and insect pest performance has been reported in monocot and dicot host plants (Table 1). For disease and insect pest control, silicon presents both economically viable method and environmentally friendly approach (Van Bockhaven et al., 2013; Liang et al., 2015a,b; Reynolds et al., 2016; Sakr, 2016a,b, 2017).

In low-silicon soils, silicon fertilizer has been recommended for use due to enhanced plant tolerance capacity to abiotic and biotic stresses, highlighting its critical function in sustainable agricultural yield (Heckman, 2013). Ma and Yamaji (2006) noted that many important plant crops are not capable of both silicon absorption form the soil and its translocation to higher organs as shoots and leaves (see the previous section on Silicon in plants). Adding silicon to plants as a fertilizer made them more resistant to various pathogenic causal agents and insect pests. So, two major sources of available silicon have been used to deliver silicon to the plant: solid and liquid sources. Solid source as calcium silicate $\left(\mathrm{CaSiO}_{3}\right)$ fertilizers which incorporate into the soil. Liquid source including potassium silicate $\left(\mathrm{K}_{2} \mathrm{SiO}_{3}\right)$ or sodium silicates $\left(\mathrm{Na}_{2} \mathrm{SiO}_{3}\right)$ which apply as a soil drench or as a foliar spray (Heckman, 
2013; Datnoff and Heckman, 2014). A good source of silicate fertilizers to diseases and insect pest control should provide a high content of soluble silicon, be inexpensive, have physical characteristics facilitating storage ability and simple application, and have uncontaminated ability with heavy metals (Heckman, 2013; Datnoff and Heckman, 2014).

Remarkable resistance of elicitors (the biocompatible molecules, biological agents and synthetic compounds) in combined with silicon against disease and insect pest damage has been the subject of several studies, for example, acibenzolar-S-methyl in minimizing the incidence of Phakopsora pachyrhizi (Asian rust) on soybean (Cruz et al., 2014) and performance of the sunflower caterpillar Chlosyne lacinia saundersii Doubleday and Hewitson (Lepidoptera: Nymphalidae) larvae on sunflower (Assis et al., 2015), antagonistic yeasts in reducing the severity of Blumeria graminis f. sp. tritici (powdery mildew) on wheat (De Curtis et al., 2012) and Acidovorax citrulli (bacterial blotch) on melon (Conceicao et al., 2014), and chitosan in decreasing the occurrence of Ralstonia solanacearum (bacterial wilt) on tomato (Kiirika et al., 2013) and Botrytis cinerea (gray mold) on strawberry (Lopes et al., 2014).

For diseases and insect pests, the mode of silicon action in a number of components of host plant resistance could be summarized as follows (Sakr, 2016a,b, 2017): it delayed the incubation and latent periods, decreased conidial production, and reduced some features of the lesions produced by the fungal, bacterial and viral diseases (expansion rate, size and number), and decreased development, reproductive period, longevity, and fecundity of insect pests. Subsequently, disease development and pest preference rates were dramatically decreased, and the resistance of susceptible cultivars was in some cases raised to nearly the same level as that of cultivars with complete or partial resistance. Moreover, for susceptible and partial cultivars, the observed disease and insect pest resistance was greatest when silicon was applied to the soil and was root-absorbed because it increases the plant's defense responses to both foliar and root infections as oppose to when it applied to the foliage. This is mainly due to the silicon transporters which were not expressed in the leaves. Regarding foliar sprays, the disease and insect pest suppressive effects observed were probably due to silicon being deposited on the leaf surface and hading an osmotic of $\mathrm{pH}$ effect. However, the underlying mechanisms that govern disease and insect pest protection when silicon is root-absorbed remain largely unclear.

Fungal pathogens

Numerous studies have shown increased plant resistance to fungal pathogens different in their lifestyles as a response to silicon application (Table 1). Another interesting association was the seemingly stronger efficacy of silicon against biotrophic and hemibiotrophic pathogens (e.g. rice blast, powdery mildews) compared to necrotrophs (Belanger et al., 2014).

\section{Necrotrophic fungal pathogens}

It has been demonstrated that silicon increases host resistance to necrotrophs as observed for barley-Alternaria spp. (black point) (Kunoh and Ishizaki, 1975), wheat-Septoria nodorum (leaf and glume blotch) (Leusch and Buchenauer, 1989), cucumber-Pythium ultimum, -Pythium aphanidermatu (root rot) (Cherif et al., 1992), maize-Pythium aphani- 
dermatum (damping off, root and stem rots) (Sun et al., 1994), pea-Mycospaerella pinodes (ascochyta blight) (Dann and Muir, 2002), coffee-Cercospora coffeicola (Cercospora leaf spot) (Pozza et al., 2004), cherry-Penicillium expansum (blue mold decay), -Monilinia fructicola (brown rot decay) (Qin and Tian, 2005), melon-Pythium aphanidermatum (root rot) (Heine et al., 2007), potato-Fusarium sulphureum (wilt) (Li et al., 2009), bananaMycosphaerella fijiensis (black sigatoka) (Kablan et al., 2012), and strawberry-Botrytis cinerea (gray mold) (Lopes et al., 2014) interactions. Huang et al. (2011) showed that foliar silicon application at the dose of $100 \mathrm{mg} \mathrm{Si} / \mathrm{L}$ in tomato plants significantly reduced the intensity of F. oxysporum f. sp. radicis-lycopersici (Fusarium crown and root rot); data proposed that the slow beginning process of the initial infection of roots and limiting movement of the pathogen from roots to stems may probably reduce the incidence of disease (Huang et al., 2011).

\section{Hemibiotrophic fungal pathogens}

Several studies observed a positive effect of silicon in decreasing the intensity of hemibiotrophic fungal pathogens as recorded in the pathoysytems of Diplocarpon rosae (black spot)-rose (Gillman et al., 2003), Phytophthora capsici (Phytophthora blight)-bell pepper (French-Monar et al., 2010), Colletotrichum sublineolum (anthracnose)-sorghum (Resende et al., 2013), C. lindemuthianum (anthracnose)-bean (Polanco et al., 2014), and Pyricularia oryzae (blast)-wheat (Cruz et al., 2015). Domiciano et al. (2015) found that silicon applications of $2 \mathrm{mM}$ reduced the severity of blast disease (Magnaporthe oryzae, anamorph Pyricularia grisea) in rice plants.

\section{Biotrophic fungal pathogens}

The association between silicon and reduced severity of biotrophic pathogens has been documented in wheat-Erysiphe graminis (powdery mildew) (Leusch and Buchenauer, 1989), cucumber and muskmelon-Sphaerotheca fuliginea and zucchini squash-Erysiphe cichoracearum (powdery mildew) (Menzies et al., 1992), grape-Uncinula necator (powdery mildew) (Bowen et al., 1992), Arabidopsis-Erysiphe cichoracearum (powdery mildew) (Ghanmi et al., 2004), pearl millet-Sclerospora graminicola (downy mildew) (Deepak et al., 2008), sugarcane-Puccinia melanocephala (rust) (Naidoo et al., 2009), bean-Pseudocercospora griseola (angular leaf spot) (Rodrigues et al., 2010), strawberryPestalotia longisetula (Pestalotia leaf spot) (Carre-Missio et al., 2010), soybean-Phakopsora pachyrhizi (Asian rust) (Arsenault-Labrecque et al., 2012), coffee-Hemileia vastatrix (rust) (Carre-Missio et al., 2012), and rose-Podosphaera pannosa (powdery mildew) (Shetty et al., 2012) interactions. Dallagnol et al. (2015) found that silicon root application was more effective compared to foliar application in reducing the intensity of powdery mildew (Podosphaera xanthii) on melon.

\section{Bacterial pathogens}

Successes in pathosystems in which the association between silicon and reduced severity of bacterial diseases have been reported in epiphytic and endophytic bacterium pathogens (Table 1). 


\section{Epiphytic bacterial pathogens}

Two studies showed that application of silicon to plants augmented resistance to epiphytic bacterial pathogens as Pseudomonas syringae pv. syringae caused bacterial apical necrosis on mango (Gutierrez-Barranquero et al., 2012) and P. syringae pv. tomato caused bacterial speck on tomato (Andrade et al., 2013).

\section{Endophytic bacterial pathogens}

Effective silicon applications in controlling endophytic bacterial pathogens was associated with bacterial wilt (Ralstonia solanacearum) on tomato (Diogo and Wydra, 2007), bacterial spot (Xanthomonas axonopodis pv. passiflorae) on passion fruit (Brancaglione et al., 2009), bacterial streak (X. translucens pv. undulosa) on wheat (Silva et al., 2010), angular leaf spot (X. citri subsp. malvacearum) on cotton (Oliveira et al., 2012), bacterial wilt ( $R$. solanacearum) on sweet pepper (Alves et al., 2015), and bacterial blight (X. oryzae pv. oryza) on rice (Song et al., 2016). Compared to control plants, reducing of bacterial blotch incidence by $50 \%$, disease index by $89 \%$, and area under the disease progress curve by $85 \%$ and increasing the incubation period by $192 \%$ was due to calcium silicate soil incorporation at the dose of $1.41 \mathrm{~g} \mathrm{Si} \mathrm{kg}^{-1}$, and covered protection for 20 days to melon plants from infection by Acidovorax citrulli (Ferreira et al., 2015).

\section{Viral pathogens}

Silicon application suppresses some viral pathogens (Table 1) as Cucumber mosaic virus (Holz et al., 2014) and Papaya ring spot virus (Elsharkawy and Mousa, 2015) on cucumber. Silicon treatments at the dose of $0.1 \mathrm{mM}$ to the majority of tobacco plants caused an absence of systemic Tobacco ringspot virus symptoms in the majority of tobacco plants compared to controls, and the slow formation of virus systemic symptom was observed in plants grown in higher silicon rates (Zellner et al., 2011).

\section{Insect pests}

Silicon can improve plant resistance to insect attack and infestation for lepidopteran borer and sap-feeding pest insects in spite of differences regarding reproductive and feeding behaviour on crops of great economic importance (Table 1).

\section{Lepidopteran borer insect pests}

A number of studies have shown increased plant resistance to lepidopteran borer pests as a response to silicon application as Asian borer Ostrinia furnacalis Guenee (Crambidae) on maize (Horng and Chu, 1990), African borer Eldana saccharina Walker (Pyralidae) on sugarcane (Kvedaras and Keeping, 2007), leaf-worm Alabama argillacea Hubner (Noctuidae) on cotton (Tomquelski et al., 2007), African armyworm Spodoptera exempta Walker (Noctuidae) on grass species (Massey and Hartley, 2009), and leaf-miner Tuta absoluta Meyrick (Gelechiidae) on tomato (dos Santos et al., 2015). Low and high 


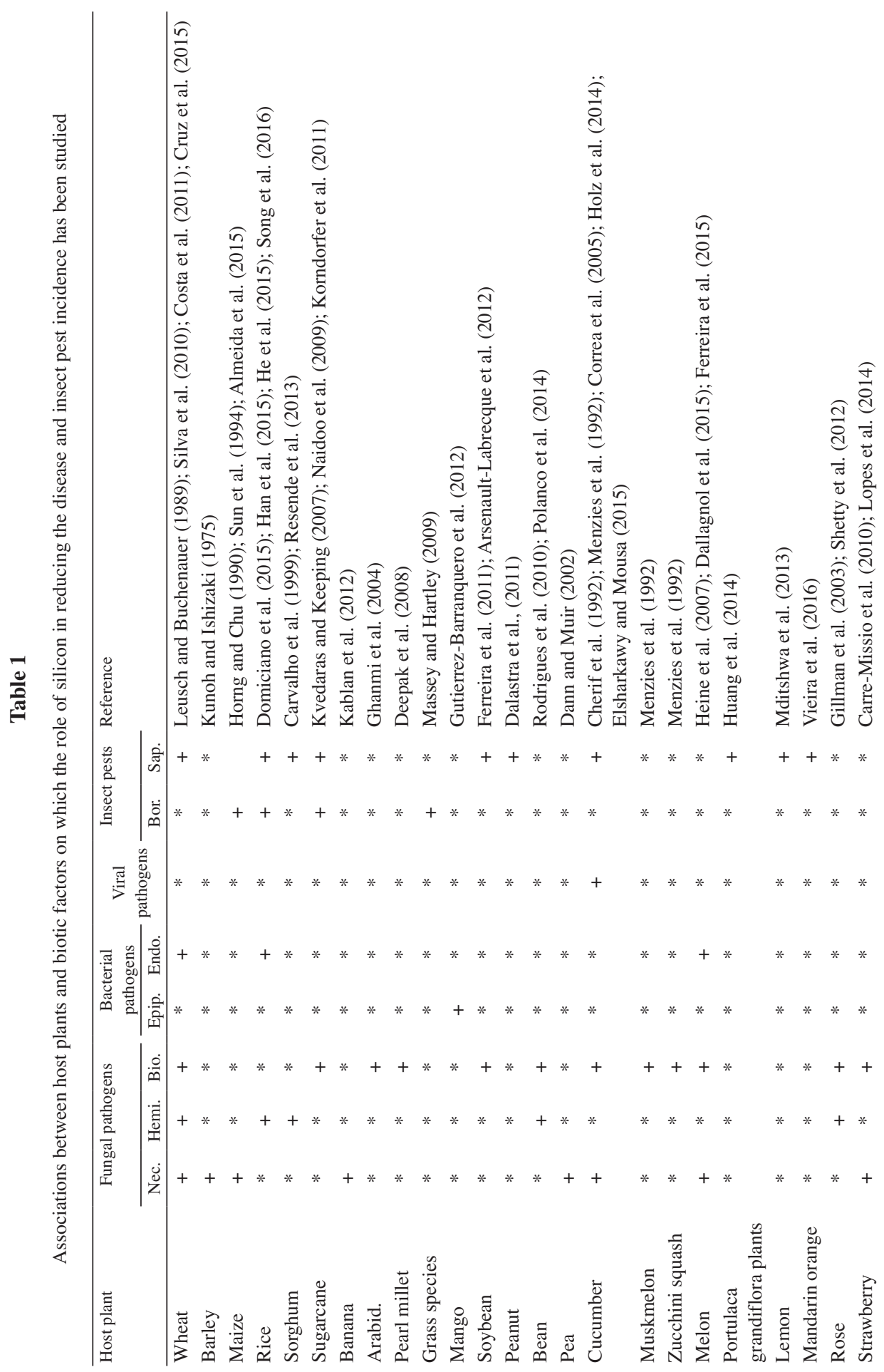




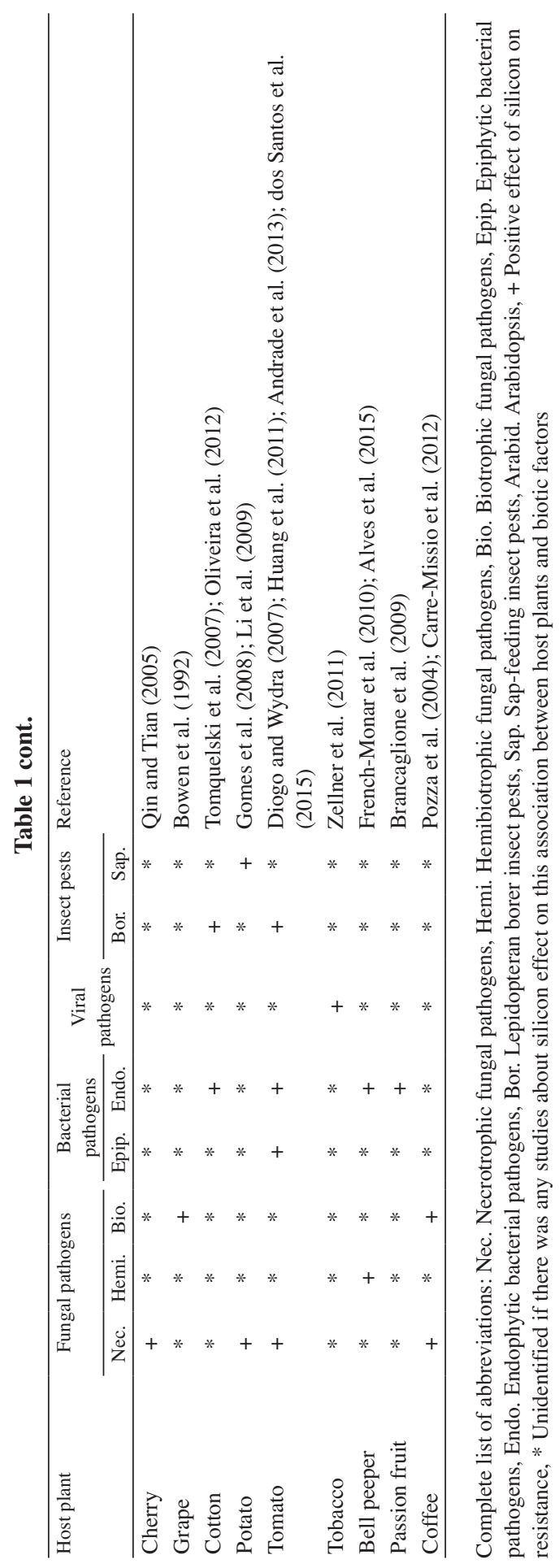


silicon levels applied to susceptible rice variety reduced larval survival rate and pupation rate in the Cnaphalocrocis medinalis Guenee (Pyralidae) (Han et al., 2015).

Sap-feeding insect pests

Numerous studies have indicated that silicon application can reduce the performance of sap-feeding pest insects as green bug Schizaphis graminum Rondani (Hemiptera: Aphididae) on sorghum (Carvalho et al., 1999), whitefly Bemisia tabaci Gennadius (Hemiptera: Aleyrodidae) on cucumber (Correa et al., 2005), and on soybean (Ferreira et al., 2011) green peach aphid Myzus persicae Sulzer (Hemiptera: Aphididae) on potato (Gomes et al., 2008), spittlebug Mahanarva fimbriolata Stal (Hemiptera: Cercopidae) on sugarcane (Korndorfer et al., 2011), Silvering thrips Enneothrips flavens Moulton (Thysanoptera: Thripidae) on peanut (Dalastra et al., 2011), Mediterranean fruit fly Ceratitis capitata Wiedemann (Diptera: Tephritidae) on lemon (Mditshwa et al., 2013), mealy-bug Phenacoccus solenopsis Tinsley (Hemiptera: Pseudococcidae) on Portulaca grandiflora plants (Huang et al., 2014), brown plant-hopper Nilaparvata lugens Stal (Hemiptera: Delphacidae) on rice (He et al., 2015), leaf aphid Rhopalosiphum maidis Fitch (Hemiptera: Aphididae) on maize (Almeida et al., 2015), and citrus black-fly Aleurocanthus woglumi Ashby (Homoptera: Aleyrodidae) on mandarin orange (Vieira et al., 2016). Positive effects of silicon treatment were evident as reduced preference, longevity and fecundity rates, nymph production- and feeding times by nymphs of green bug Schizaphis graminum (Rondani) (Hemiptera: Aphididae) on wheat (Costa et al., 2011).

\section{Mechanisms of silicon-enhanced resistance}

The effect of silicon on the control of plant diseases and insect pests, its mode of action, its properties, and its spectrum of efficacy in several biological systems is not entirely understood and require more research both under farm conditions and as tissue culture (Van Bockhaven et al., 2013; Liang et al., 2015a,b; Reynolds et al., 2016; Sakr, 2016a,b, 2017). In the absence of abiotic and/or biotic stresses, silicon was believed to have a negligible effect on plant growth or development (Ma and Yamaji, 2006). However, beneficial and useful effects only manifest under stress conditions (Epstein, 2009).

In general, the effect of silicon on resistance of plants to diseases and insect pests is considered to be due to either a deposition of silicon on cell walls acting as a mechanical barrier difficult the pathogens and insect pests attack, or biochemical changes related to plant defense (Fig. 1) (Van Bockhaven et al., 2013; Liang et al., 2015a,b; Reynolds et al., 2016; Sakr, 2016a,b, 2017). Importance of the two mechanisms of defense in enhancing silicon-treated-plant resistance may differ according to the biotic agents (Van Bockhaven et al., 2013; Reynolds et al. 2016; Sakr, 2016a,b, 2017). On one hand, physical defense is most widely accepted mechanism for the action of silicon in augmenting plant resistance to insect pest infestation (Reynolds et al., 2016; Sakr, 2017). On the other hand, induced biochemical defense is most involved in augmenting plant resistance to fungal and bacterial pathogens (Van Bockhaven et al., 2013; Sakr, 2016a,b). Also, other resistance mechanisms to some bacterium and viral pathogens have been reported. Foliar silicon accumulation in tobacco leaves may be part of a defense response to Tobacco ringspot 
virus, and the silicon influence seemed to be virus-specific (Zellner et al., 2011). Andrade et al. (2013) noticed that a direct effect of silicon treatments to tomato plants was associated with reducing bacterial speck symptoms, and the authors observed that host defense enzymes did not contribute with resistance to Pseudomonas syringae pv. tomato.

\section{Physical defense}

For the first hypothesis of silicon-physical enhanced resistance, silicon deposited on the tissue surface acts as a physical barrier that protects plants from pathogen infection and pest invasion (Van Bockhaven et al., 2013; Liang et al., 2015a,b; Reynolds et al., 2016; Sakr, 2016a,b, 2017). Silicon might form complexes with organic compounds in the walls of the epidermal cells, therefore increasing their resistance to degradation by enzymes released by pathogenic causal agents and insect pests. Furthermore, plant resistance in restricting pest feeding may not be simply related to the total quantity of silicon per se, but due to the site, arrangement and organization of silicon in the plant (Sakr, 2016a,b, 2017).

Three silicon mechanisms governed resistance in plants to infection of fungi and bacteria have been proposed; the first one suggests that silicon prevented physical penetration by pathogens, second one is related to strengthening of plant organs mechanically by silicon application, and the third one is associated with decreasing of enzymatic degradation by fungal and bacterial pathogens making the plant cell more hard. Bowen et al. (1992) noticed that silicon layer formation in the leaf cuticle of vine seedlings due to potassium silicate application at concentration of $17 \mathrm{mmol} \mathrm{L}^{-1}$ reduced significantly penetration of Uncinula necator (powdery mildew). Contrary, higher intensity of the disease was observed in non-treated leaf areas (Bowen et al., 1992). Also, Kim et al. (2002) found that dilatation of penetration of Pyricularia grisea (blast) in rice leaves was due to cuticle-silica double layer. Two silicon defense mechanisms by which silicon deposition acts as a physical barrier to pest attack have been proposed. First, silicon decreases the efficiency with which insect pests can digest plant leaves. Second, increased hardness and abrasiveness of plant tissues due to silicon may increase the wear on insect pest mouthparts, both of which could potentially impact on insect pest performance. Chu and Horng (1991) observed that increased hardness level in stems to Asian corn borer Ostrinia furnacalis Chillo suppressalis Walker (Lepidoptera: Crambidae) was due to calcium silicate slag applied to corn plants, and tissue hardness rates decreased the consumption of the leaves by pest, indicating that leaf hardness and abrasiveness due to high silica deposition may be associated with the resistance to the borer. Rapid increasing in mandible wear of the African armyworm Spodoptera exempta Walker (Lepidoptera: Noctuidae) was due to silicon fertilization to grass species (Massey and Hartley, 2009).

\section{Biochemical defense}

Regarding the second hypothesis of silicon-biochemical enhanced resistance, the soluble silicon in plant tissue may be associated with an increase in resistance to diseases and insect pests (Van Bockhaven et al., 2013; Liang et al., 2015a,b; Reynolds et al., 2016; Sakr, 2016a,b, 2017). Induced plant defenses could also be involved after silicon absorption. A series of biochemical changes has been reported in silicon-treated plants. 
In this model, the soluble silicon in plant tissue may induce plant defense against disease and insect pest attack via (1) enhanced activity of defense-related enzymes, such as polyphenoloxidase, peroxidase, phenylalanine ammonia-lyase, and glucanase in leaves, (2) increased production of anti-disease and -insect compounds and defensive chemicals, such as phenolic metabolism product (lignin), flavonoids, phytoalexins and pathogenesis-related proteins in plants, and (3) activation of some plant defense-related genes.

Silicon treatments to melon plants enhanced concentrations of chitinase, superoxide dismutase, peroxidase, $\beta$-1,3-glucanase and lignin and consequently reduced intensity of powdery mildew (Podosphaera xanthii) (Alves et al., 2015). Increased activation of total protein, catalase, ascorbate peroxidase, and chitinase concentration decreased the incidence of Ralstonia solanacearum on sweet pepper plants treated with calcium silicate (Dallagnol et al., 2015). Increased activities of peroxidase and polyphenoloxidase in seedlings of mandarin orange due to potassium silicate application reduced development of citrus black-fly Aleurocanthus woglumi Ashby (Homoptera: Aleyrodidae) (Vieira et al., 2016). Ghareeb et al. (2011) found that silicon application to tomato plant infected with $R$. solanacearum induced changes in gene expression which prime the defense capacity. Enhancing of the expression of all defense-related genes in response to Pyricularia oryzae (blast) infection was due to silicon application to wheat plants (Cruz et al., 2015). Expression of the majority of various pathogen-related genes was meditated by silicon treatment in cucumber plants to Papaya ring spot virus (Elsharkawy and Mousa, 2015).

\section{Conclusion}

In crops of great economic importance, silicon presents both economically viable method and environmentally friendly approach for disease and insect pest control in sustainable crop production. Two major defense mechanisms due to silicon application to diseases and insect pests have been documented: physical defense and induced biochemical defense. It seems that the physical defense due to silica deposition is more acceptable mechanism than a biochemical resistance for the action of silicon in increasing plant resistance to insect pest infestation. Induced biochemical defense is most involved in augmenting plant resistance to fungal and bacterial pathogens over silicon function as a mechanical barrier. Silicon effect to enhance plant resistance against diseases and insect pests is not limited to high silicon-accumulators, and has been described in intermediate and low accumulators. Recent progress in understanding the biological role of silicon in plants will be valuable to the effective use of silicon to increase crop productivity and enhance disease and insect pest resistance.

\section{Acknowledgements}

I would like to thank the Professor I. Othman Director General of AECS and Professor F. Kurdali Head of the Agriculture Department for their continuous support of this research. 


\section{Literature}

Almeida, A. C. de Sousa., Silva, L. P., de Jesus, F. G., Nogueira, L., Neto, M. de Sousa and da Cunha, P. C. R. (2015): Effects of the resistance inducers in attractiveness to aphid Rhopalosiphum maidis (Fitch, 1856) (Hemiptera: Aphididae) in corn. Rev. Agrar. 8, 23-29.

Alves, A. O., Santos, M. M. B., Souza, L. J. N., Souza, E. B. and Mariano, R. L. R. (2015): Use of silicon for reducing the severity of bacterial wilt of sweet pepper. J. Plant Patholo. 97, 419-429.

Andrade, C. C. L., Resende, R. S., Rodrigues, F. A., Ferraz, H. G. M., Moreira, W. R., Oliveira, J. R. and Mariano R. L. R. (2013): Silicon reduces bacterial speck development on tomato leaves. Trop. Plant Pathol. $38,436-442$.

Arnon, D. and Stout, P. (1939): The essentiality of certain elements in minute quantity for plants with special reference to copper. Plant Physiol. 14, 371-375.

Arsenault-Labrecque, G., Menzies, J. G. and Belanger, R. R. (2012): Effect of silicon absorption on soybean resistance to Phakopsora pachyrhizi in different cultivars. Plant Dis. 96, 37-42.

Assis, F. A., Moraes, J. C., Assis, G. A. and Parolin, F. J. T. (2015): Induction of caterpillar resistance in sunflower using silicon and Acibenzolar-S-Methyl. J. Agr. Sci. Tech. 17, 543-550.

Bayles, R. A., Flath, K., Hovmoller, M. S. and de Vallavieille-Pope, C. (2000): Breakdown of the Yr17 resistance to yellow rust of wheat in northern Europe. Agronomie 20, 805-811.

Bazilevich, N. I. (1993): The biological productivity of North Eurasian ecosystems. RAS Institute of Geography, pp. 1-293.

Belanger, R. R, Vivancos, J., Wilkinson, J. A., Belzile, F. and Menzies, J. G. (2014): Silicon influence on biotic stress in plants. In Proc. of the $6^{\text {th }}$ International Conference on Silicon in Agriculture, Stockholm, Sweden, 26-30 August, $42 \mathrm{p}$.

Bowen, P., Menzies, J. and Ehret, D. (1992): Soluble silicon sprays inhibit powdery mildew development on grape leaves. J. Am. Soc. Hortic. Sci. 117, 906-912.

Brancaglione, P., Sampaio, A. C., Fischer, I. H., Almeida, A. M. and Fumis, T. F. (2009): Analysis of the efficiency of silicate clay on the control of Xanthomonas axonopodis pv. passiflorae in vitro and in seedlings of yellow passion fruit contaminated. Rev. Bras. Frutic. 31, 718-724.

Carre-Missio, V., Rodrigues, F. A., Schurt, D. A., Rezende, D. C., Ribeiro, N. B. and Zambolim, L. (2010): Foliar application of potassium silicate, acibenzolar-S-methyl and fungicides on the reduction of Pestalotia leaf spot on strawberry. Trop. Plant Pathol. 35, 182-185.

Carre-Missio, V., Rodrigues, F. A., Schurt, D. A., Rezende, D. C., Moreira, W. R., Korndorfer, G. H. and Zambolim, L. (2012): Epidemiological components of coffee rust affected by foliar application of potassium silicate. Trop. Plant Pathol. 37, 50-56.

Carvalho, S. P., Moraes, J. C. and Carvalho, J. G. (1999): Silica effect on the resistance of Sorghum bicolor (L.) Moench to the greenbug Schizaphis graminum (Rond.) (Homoptera: Aphididae). An. Soc. Entomol. Bras. 28, 505-510.

Cherif, M., Menzies, J. G., Benhamou, N. and Belanger, R. R. (1992): Studies of silicon distribution in wounded and Pythium ultimum infected cucumber plants. Physiol. Mol. Plant Pathol. 41, 371-385.

Chu, Y. I. and Horng, S. B. (1991): Infestation and reproduction of Asia corn borer on slag-treated corn plants. Chin. J. Entomol. 11, 19-24.

Conceicao, C. S., Felix, K. C. S., Mariano, R. L. R., Medeiros, E. V., Elineide, B. and Souza, E. B. (2014): Combined effect of yeast and silicon on the control of bacterial fruitblotch in melon. Sci. Hort. 174, 164-170.

Cooksey, D. A. (1990): Genetics of bactericide resistance in plant pathogenic bacteria. Annu. Rev. Phytopathol. 28, 201-219.

Correa, R. S., Moraes, J. C., Auad, A. M. and Carvalho, G. A. (2005): Silicon and acibenzolar-S-methyl as resistance inducers in cucumber, against the whitefly Bemisia tabaci (Gennadius) (Hemiptera: Aleyrodidae) biotype B. Neotrop. Entomol. 34, 429-433.

Costa, R. R., Moraes, J. C and Costa, R. R. (2011): Feeding behaviour of the greenbug Schizaphis graminum on wheat plants treated with imidacloprid and/or silicon. J. Appl. Entomol. 135, 115-120.

Cruz, M. F. A., Rodrigues, F. A., Diniz, A. P. C., Alves Moreira, M. and Barros, E. G. (2014): Soybean resistance to Phakopsora pachyrhizi as affected by acibenzolar-S-methyl, jasmonic acid and silicon. J. Phytopathol. 162, 133-136. 
Cruz, M. F. A., Debona, D., Rios, J. A., Barros, E. G. and Rodrigues, F. A. (2015): Potentiation of defense-related gene expression by silicon increases wheat resistance to leaf blast. Trop. Plant Pathol. 40, 394-400.

Dalastra, C., Campos, A. R., Fernandes, F. M., Martins, Gustavo, L. and Campos, Z. R. (2011): Silicon as a resistance inducer controlling the silvering thrips Enneothrips flavens Moulton, 1941 (Thysanoptera: Thripidae) and its effects on peanut yield. Cienc. Agrotec. 35, 531-538.

Dallagnol, L. J., Rodrigues, F. A., Pascholati, S. F., Fortunato, A. A. and Camargo, L. E. A. (2015): Comparison of root and foliar applications of potassium silicate in potentiating post-infection defences of melon against powdery mildew. Plant Pathol. 64, 1085-1093.

Dann, E. and Muir, S. (2002): Peas grown in media with elevated plant-available silicon levels have higher activities of chitinases and $\beta$-1,3-glucanase, are less susceptible to a fungal leaf spot pathogen and accumulate more foliar silicon. Aust. Plant Pathol. 31, 9-13.

Datnoff, L., Elmer, W. and Huber, D. (2007): Mineral nutrition and plant disease. The American Phytopathological Society, pp. 1-278.

Datnoff, L. E. and Heckman, J. R. (2014): Silicon fertilizers for plant disease protection. In Proc. of the 16th World Fertilizer Congress of CIECRio. De Janeiro-RJ, Brazil, 20-24 October, pp. 37-38.

De Curtis, F., De Cicco, V. and Lima, G. (2012): Efficacy of biocontrol yeasts combined with calcium silicate or sulphur for controlling durum wheat powdery mildew and increasing grain yield components. Field Crops Res. 134, 36-46.

Deepak, S., Manjunath, G., Manjula, S., Niranjan-Raj, S., Geetha, N. P. and Shetty, H. S. (2008): Involvement of silicon in pearl millet resistance to downy mildew disease and its interplay with cell wall proline/ hydroxyproline-rich glycoproteins. Australas Plant Pathol. 37, 498-504.

Denholm, I. and Rowland, M. W. (1992): Tactics for managing pesticide resistance in arthropods: theory and practice. Annu. Rev. Entomol. 37, 91-112.

Diogo, R. V. C. and Wydra, K. (2007): Silicon-induced basal resistance in tomato against Ralstonia solanacearum is related to modification of pectic cell wall polysacharide structure. Physiol. Mol. Plant Pathol. $70,120-129$.

Domiciano, G., Cacique, I., Freitas, C., Filippi, M., DaMatta, F. M., Vale, F. and Rodrigues, F. (2015): Alterations in gas exchange and oxidative metabolism in rice leaves infected by Pyricularia oryzae are attenuated by silicon. Phytopathology 105, 738-747.

dos Santos, M. C., Resende Junqueira, A. M., Mendes de Sa, V. G., Zanuncio, J. C. and Serrao, J. E. (2015): Effect of silicon on the morphology of the midgut and mandible of tomato leafminer Tuta absoluta (Lepidoptera: Gelechiidae) larvae. Invertebrate Surviv. J. 12, 158-165.

Dubin, H. J. and Rajaram, S. (1996): Breeding disease-resistant wheats for tropical highlands and lowlands. Annu. Rev. Phytopathol. 34, 503-526.

Elsharkawy, M. M. and Mousa, K. M. (2015): Induction of systemic resistance against Papaya ring spot virus (PRSV) and its vector Myzus persicae by Penicillium simplicissimum GP17-2 and silica $\left(\mathrm{SiO}_{2}\right)$ nanopowder. Int. J. Pest Manage. 61, 353-358.

Epstein, E. (1994): The anomaly of silicon in plant biology. Proc. Nat. Acad. Sci. USA 91, 11-17.

Epstein, E. (1999): Silicon. Annu. Rev. Plant. Biol. 50, 641-664.

Epstein, E. (2009): Silicon: Its manifold roles in plants. Ann. Appl. Biol. 155, 155-160.

Epstein, E. and Bloom, A. J. (2005): Mineral Nutrition of Plants: Principles and Perspectives. Sinauer Associates, Sunderland, MA. USA, pp. 1-600.

Ferreira, R. S., Moraes, J. C. and Antunes, C. S. (2011): Silicon influence on resistance induction against Bemisia tabaci biotype B (Genn.) (Hemiptera: Aleyrodidae) and on vegetative development in two soybean cultivars. Neotrop. Entomol. 40, 495-500.

Ferreira, H. A, do Nascimento, C. W. A., Datnoff, L. E., de Sousa Nunes, G. H., Preston, W., de Souza, E. B. and de Lima, M. R. (2015): Effects of silicon on resistance to bacterial fruit blotch and growth of melon. Crop Prot. 78, 277-283.

French-Monar, R. D., Rodrigues, F. A., Korndorfer, G. H. and Datnoff, L. E. (2010): Silicon suppresses Phytophthora blight development on bell pepper. J. Phytopathol. 158, 554-560.

Ghanmi, D., McNally, D. J., Benhamou, N., Menzies, J. G. and Belanger, R. R. (2004): Powdery mildew of Arabidopsis thaliana: A pathosystem for exploring the role of silicon in plant-microbe interactions. Physiol. Mol. Plant Pathol. 64, 189-199. 
Ghareeb, H., Bozso, Z., Ott, P. G., Repenning, C., Stahl, F. and Wydra K. (2011): Transcriptome of siliconinduced resistance against Ralstonia solanacearum in the silicon non-accumulator tomato implicates priming effect. Physiol. Mol. Plant Pathol. 75, 83-89.

Gillman, J., Zlesak, D. and Smith, J. (2003): Applications of potassium silicate decrease black spot infection of Rosa hybrida 'Meilpelta'. HortScience 38, 144-147.

Gomes, F. B., Moraes, J. C. and Antunes, C. S. (2008): Use of silicon as inductor of the resistance in potato to Myzus persicae (Sulzer) (Hemiptera: Aphididae). Neotrop. Entomol. 37, 185-190.

Gutierrez-Barranquero, J. A., Arrebola, E., Bonilla, N., Sarmiento, D., Cazorla, F. M. and de Vicente, A. (2012): Environmentally friendly treatment alternatives to Bordeaux mixture for controlling bacterial apical necrosis (BAN) of mango. Plant Pathol. 61, 665-676.

Han, Y., Lei, W., Wen, L. and Hou, M. (2015): Silicon-mediated resistance in a susceptible Rice variety to the rice leaf folder, Cnaphalocrocis medinalis Guenée (Lepidoptera: Pyralidae). PLoS One 10: e0120557.

He, W., Yang, M., Li, Z., Qiu, J., Liu, F. and Qu, X. (2015): High levels of silicon provided as a nutrient in hydroponic culture enhances rice plant resistance to brown planthopper. Crop Prot. 67, 20-25.

Heckman, J. (2013): Silicon: A beneficial substance. Better Crops 97, 14-16.

Heine, G., Tikum, G. and Horst, W. (2007): The effect of silicon on the infection by and spread of Pythium aphanidermatum in single roots of tomato and bitter gourd. J. Exp. Bot. 58, 569-577.

Holz, S., Zeise, I., Bartoszewski, G., Kneipp, J., Kube, M. and Buttner, C. (2014): Insights into molecular impact of silica on virus infected cucumber cultures. In Proc. of the $6^{\text {th }}$ International Conference on Silicon in Agriculture, Stockholm, Sweden, 26-30 August, 2014, 88. p.

Horng, S. B. and Chu, Y. I. (1990): Development and reproduction of Asian corn borer (Ostrinia furnacalis Guenee) fed on artificial diet containing silica. Chin. J. Entomol. 10, 325-335.

Huang, C. H., Roberts, P. D. and Datnoff, L. E. (2011): Silicon suppresses Fusarium crown and root rot of tomato. J. Phytopathol. 159, 546-554.

Huang, J., Zhang, J., Wang, D., Zhang, L., Xu, Y. and Li, M. (2014): Do organic silicon and imidacloprid synergistically induce toxicity to the new invasive mealybug Phenacoccus solenopsis Tinsley on Portulaca grandiflora plants? Turk. J. Agric. For. 38, 207-213.

Kablan, L., Lagauche, A., Delvaux, B. and Legreve, A. (2012): Silicon reduces black sigatoka development in banana. Plant Dis. 96, 273-278.

Kiirika, L. M., Stahl, F. and Wydra, K. (2013): Phenotypic and molecular characterization of resistance induction by single and combined application of chitosan and silicon in tomato against Ralstonia solanacearum. Physiol. Mol. Plant Pathol. 81, 1-12.

Kim, S. G., Kim, K. W., Park, E. W. and Choi, D. (2002): Silicon-induced cell wall fortification of rice leaves: a possible cellular mechanism of enhanced host resistance to blast. Phytopathology 92, 1095-1103.

Korndorfer, A. P., Grisoto, E. and Vendramim, J. D. (2011): Induction of insect plant resistance to the spittlebug Mahanarva fimbriolata Stål (Hemiptera: Cercopidae) in sugarcane by silicon application. Neotrop. Entomol. 40, 387-392.

Kovda, V. A. (1973): The bases of learning about soils. Nayka, pp. 1-16.

Kunoh, H. and Ishizaki, H. (1975): Silicon levels near penetration sites of fungi on wheat, barley, cucumber and morning glory leaves. Physiol. Plant Pathol. 5, 283-287.

Kvedaras, O. L. and Keeping, M. G. (2007): Silicon impedes stalk penetration by the borer Eldana saccharina in sugarcane. Entomol. Exp. Appl. 125, 103-110.

Leusch, H. and Buchenauer, H. (1989): Effect of soil treatments with silica-rich lime fertilizers and sodium trisilicate on the incidence of wheat by Erysiphe graminis and Septoria nodorum depending on the form of N-fertilizer. J. Plant Dis. Protect. 96, 154-172.

Li, Y. C., Bi, Y., Ge, Y. H., Sun, X. J. and Wang, Y. (2009): Antifungal activity of sodium silicate on Fusarium sulphureum and its effect on dry rot of potato tubers. J. Food Sci. 74, M213-M218.

Liang, Y., Sun, W., Zhu, Y. G. and Christie, P. (2007): Mechanisms of silicon-mediated alleviation of abiotic stresses in higher plants: A review. Environ. Pollut. 147, 422-428.

Liang, Y., Nikolic, M., Belanger, R., Gong, H. and Song, A. (2015a): Silicon and insect pest resistance. In: Y. Liang et al. (eds): Silicon in Agriculture, from Theory to Practice. Springer, pp. 197-207.

Liang, Y., Nikolic, M., Belanger, R., Gong, H. and Song, A. (2015b). Silicon and plant-pathogen interactions. In: Y. Liang et al. (eds): Silicon in Agriculture - from Theory to Practice. Springer, pp. 181-197. 
Liang, Y., Nikolic, M., Belanger, R., Gong, H. and Song, A. (2015c): Silicon in Agriculture, from Theory to Practice. Springer, pp. 1-325.

Lindgren, P. B. (1997): The role of $h r p$ genes during plant-bacterial interactions. Annu. Rev. Phytopathol. 35, $129-152$.

Lopes, U. P., Zambolim, L., Costa, H., Pereira, O. L. and Finger, F. L. (2014): Potassium silicate and chitosan application for gray mold management in strawberry during storage. Crop Prot. 63, 103-106.

Ma, J. F. (2004): Role of silicon in enhancing the resistance of plants to biotic and abiotic stresses. J. Soil Sci. Plant Nutr. 50, 11-18.

Ma, Z. and Michailides, T. J. (2005): Advances in understanding molecular mechanisms of fungicide resistance and molecular detection of resistant genotypes in phytopathogenic fungi. Crop Prot. 24, 853-863.

Ma, J. F. and Yamaji, N. (2006): Silicon uptake and accumulation in higher plants. Trends Plant Sci. 11, 392-397.

Ma, J. F. and Yamaji, N. (2008): Functions and transport of silicon in plants. Cell Mol. Life Sci. 65, 3049-3057.

Ma, J. F., Yamaji, N. and Mitani-Ueno, N. (2011): Transport of silicon from roots to panicles in plants. Proc. Jpn. Acad. Ser. B Phys. Biol. Sci. 87, 377-385.

Massey, F. P. and Hartley, S. E. (2009): Physical defences wear you down: progressive and irreversible impacts of silica on insect herbivores. J. Anim. Ecol. 78, 281-291.

Mditshwa, A., Bower, J. P., Bertling, I., Mathaba, N. and Tesfay, S. T. (2013): The potential of postharvest silicon dips to regulate phenolics in citrus peel as a method to mitigate chilling injury in lemons. Afr. J. Biotechnol. 12, 1482-1489.

Menzies, J., Bowen, P., Ehret, D. L. and Glass, A. D. M. (1992): Foliar applications of potassium silicate reduce severity of powdery mildew on cucumber, muskmelon, and zucchini squash. J. Am. Soc. Hortic. Sci. 117, 902-905.

Naidoo, P. V., McFarlane, S., Keeping, M. G. and Caldwell, P. M. (2009): Deposition of silicon in leaves of sugarcane (Saccharum spp. hybridus) and its effect on the severity of brown rust caused by Puccinia melanocephala. Proc. South Afr. Sugar Technol. 82, 542-546.

Oliveira, J. C., Albuquerque, G. M. R., Mariano, R. L. R., Gondim, D. M. F., Oliveira, J. T. A. and Souza, E. B. (2012): Reduction of the severity of angular leaf spot of cotton mediated by silicon. J. Plant Pathol. 94, 297-304.

Polanco, L. R., Rodrigues, F. A., Nascimento, K. J. T., Cruz, M. F. A., Curvelo, C. R. S., DaMatta, F. M. and Vale, F. X. R. (2014): Photosynthetic gas exchange and antioxidative system in common bean plants infected by Colletotrichum lindemuthianum and supplied with silicon. Trop. Plant Pathol. 39, 35-42.

Pozza, A. A. A., Alves, E., Pozza, E. A., Carvalho, J. G., Montanari, M., Guimaraes, P. T. G. and Santos, D. M. (2004): Effect of silicon on the control of brown eye spot in three coffee cultivars. Fitopatol. Bras. 29, $185-188$.

Qin, G. Z. and Tian, S. P. (2005): Enhancement of biocontrol activity of Cryptococcus laurentii by silicon and the possible mechanisms involved. Phytopathology 95, 69-75.

Reynolds, O. L., Padula, M. P., Zeng, R. and Gurr, G. M. (2016): Silicon: potential to promote direct and indirect effects on plant defense against arthropod pests in agriculture. Front. Plant Sci. 7, 744 p.

Resende, R. S., Rodrigues, F. A., Gomes, R. J. and Nascimento, K. J. T. (2013): Microscopic and biochemical aspects of sorghum resistance to anthracnose mediated by silicon. Ann. Appl. Biol. 163, 114-123.

Rizwan, M., Meunier, J. D., Miche, H. and Keller, C. (2012): Effect of silicon on reducing cadmium toxicity in durum wheat (Triticum turgidum L. cv. Claudio W.) grown in a soil with aged contamination. J. Hazard Mater. 209-210, 326-334.

Rodrigues, F. A., Duarte, H. S. S., Rezende, D. C., Filho W. J. A., Korndo, G. H. and Zambolim, L. (2010): Foliar spray of potassium silicate on the control of angular leaf spot on beans. J. Plant Nutr. 33, 2082-2093.

Sakr, N. (2016a): Silicon control of bacterial and viral diseases in plants. J. Plant Prot. Res. 56, 331-336.

Sakr, N. (2016b): The role of silicon (Si) in increasing plant resistance against fungal diseases. Hellenic Plant Protect. J. 9, 1-15.

Sakr, N. (2017): The role of silicon (Si) in increasing plant resistance against insect pests. Acta Phytopathol. et Entomol. Hung. 52, 185-204.

Savant, N., Snyder, G. and Datnoff, L. (1997): Silicon management and sustainable rice production. Adv. Agron. $58,151-199$.

Semal, J. (1989): Traité de Pathologie Végétale. Les Presses Agronomiques de Gembloux, pp. 1-621. 
Shephard, M. C. (1997): Screening for fungicides. Ann. Rev. Phytopathol. 25, 189-206.

Shetty, R., Jensen, B., Shetty, N. P., Hansen, M., Hansen, C. W., Starkey, K. R. and Jorgensen, H. J. L. (2012): Silicon induced resistance against powdery mildew of roses caused by Podosphaera pannosa. Plant Pathol. 61, 120-131.

Silva, I. T., Rodrigues, F. A., Oliveira, J. R., Pereira, S. C., Andrade, C. C. L., Silveira, R. P. and Conceic, M. M. (2010): Wheat resistance to bacterial leaf streak mediated by silicon. J. Phytopathol. 158, 253-262.

Song, A., Xue, G., Cui, P., Fan, F., Liu, H., Yin, C., Sun, W. and Liang, Y. (2016): The role of silicon in enhancing resistance to bacterial blight of hydroponic- and soil-cultured rice. Sci. Rep. 6, 24640.

Sun, X., Sun, Y., Zhang, C., Song, Z., Chen, J., Bai, J., Cui, Y. and Zhang, C. (1994): The mechanism of corn stalk rot control by application of potassic and siliceous fertilizers. Acta Phytophysiol. Sinica 21, 102-108.

Tomquelski, G. V., Martins, G. L. and Papa, G. (2007): Effect of resistance inductors acibenzolar-S-methyl and silicon in the biology of Alabama argillacea (Lepid.: Noctuidae) on crop cotton. Rev. Agric. (Piracicaba) 82, 170-175.

Ukwungwu, M. N. (1990): Host plant resistance in rice to the African striped borer, Chilo zacconius Bles. (Lepidoptera: Pyralidae). Insect Sci. Appl. 11, 639-647.

Van Bockhaven, J., Vleesschauwer, D. D. and Hofte, M. (2013): Towards establishing broad-spectrum disease resistance in plants: silicon leads the way. J. Exp. Bot. 64, 1281-1293.

Vieira, D. L., Vieira, V. de Oliveira, de Souza, W. C. O., da Silva, J. G., Malaquias, J. B. and Batista, J. de Luna. (2016): Potassium silicate-induced resistance against blackfly in seedlings of Citrus reticulate. Fruits 71, $49-55$

Zellner, W., Frantzb, J. and Leisnera, S. (2011): Silicon delays tobacco ringspot virus systemic symptoms in Nicotiana tabacum. J. Plant Physiol. 168, 1866-1869. 